\title{
Liraglutide as additional treatment to insulin in patient with latent autoimmune diabetes in adults (LADA): a case report.
}

I. Silko, T. Nikonova, M. Shestakova

Endocrinology Research Centre, Moscow, Russian Federation

\section{Introduction}

LADA exhibits characteristics of both type 1 diabetes mellitus (DM) and type 2 DM. Patients with LADA usually have some components of metabolic syndrome. GLP-1 agonists have been widely used in type 2 DM. GLP-1 agonist therapies have shown some promising glucose lowering effect in T1DM. Almost no information is available on glucagon and incretin secretion in patients with LADA as well as effects on glucose and C-peptide levels.

\section{Case report}

A 40-year old man with BMI $29.4 \mathrm{~kg} / \mathrm{m}^{2}$, diagnosed with LADA-diabetes(duration 6 months) had GADA and ICA - positive autoantibodies, fasting plasma C-peptide $1,8 \mathrm{ng} / \mathrm{ml}(1,1-4,4)$. The patient received insulin treatment. Mixed meal tolerance test (MMTT) was performed before and after treatment with liraglutide $1,8 \mathrm{mg}$ in addition to insulin during next 6 months. Plasma glucose (PG), glucagon and C-peptide were measured at 0 min, 30 and 120 min during MMTT. HbA1c was measured before and after treatment. Informed consent was obtained from the participant. After the treatment $\mathrm{HbA} 1 \mathrm{c}$ decreased from $10,5 \%$ to $7,4 \%$. Dose of long-acting insulin was reduced and fast-acting insulin was abolished. BMl reduced from $29,4 \mathrm{~kg} / \mathrm{m}^{2}$ to $26,3 \mathrm{~kg} / \mathrm{m}^{2}$. Plasma glucose decreased from $10,3 \mathrm{mmol} / \mathrm{l}$ to $6,2 \mathrm{mmol} / \mathrm{l}$ on $30 \mathrm{~min}$ and from 9,6 to $8,1 \mathrm{mmol} / \mathrm{l}$ on $120 \mathrm{~min}$. Liraglutide reduced glucagon levels from $153,2-179,3-226,7 \mathrm{pg} / \mathrm{ml}$ (on 0, 30, $120 \mathrm{~min}$ respectively) to $150-164-138 \mathrm{pg} / \mathrm{ml}$. Plasma fasting C-peptide level has become $2,3 \mathrm{ng} / \mathrm{ml}$ after 6 months.

Pic.1. Glucagon secretion during MMTT

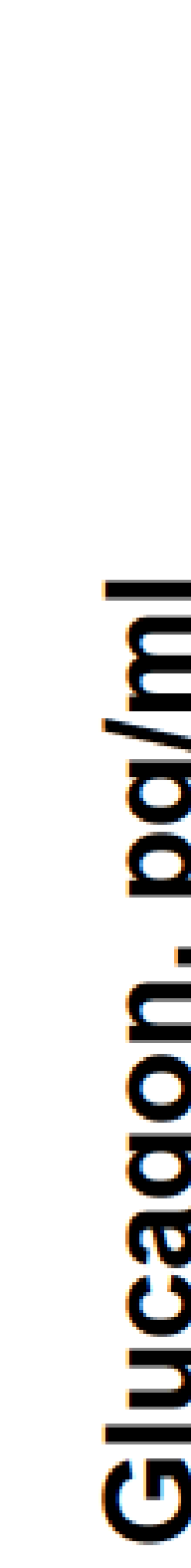

$150 \quad 164$

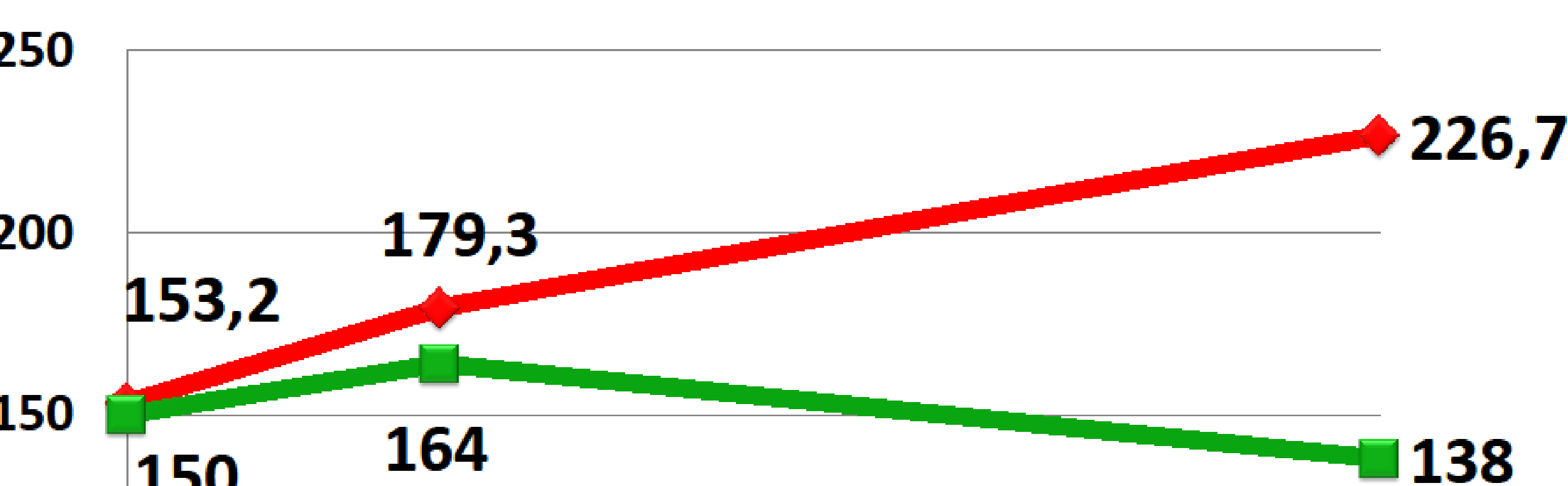

00 before the

addition of Liraglutide

$50+6$ months after the

addition of

$\mathbf{0}$

$0 \quad 30$

Table 1. Dynamics of clinical parameters before and 6 months after the addition of Liraglutide.

\begin{tabular}{|l|c|c|}
\hline \multicolumn{1}{|c|}{ Clinical parameters } & Before & After 6 month \\
\hline $\mathrm{HbA} 1 \mathrm{c}, \%$ & 10,5 & 7,4 \\
\hline $\begin{array}{l}\text { Plasma fasting } \\
\text { C-peptide, } \mathrm{ng} / \mathrm{ml}\end{array}$ & 1,8 & 2,3 \\
\hline $\mathrm{BMI}, \mathrm{kg} / \mathrm{m}^{2}$ & & \\
\hline
\end{tabular}

\section{Pic.2. Dynamics of plasma glucose during MMTT}

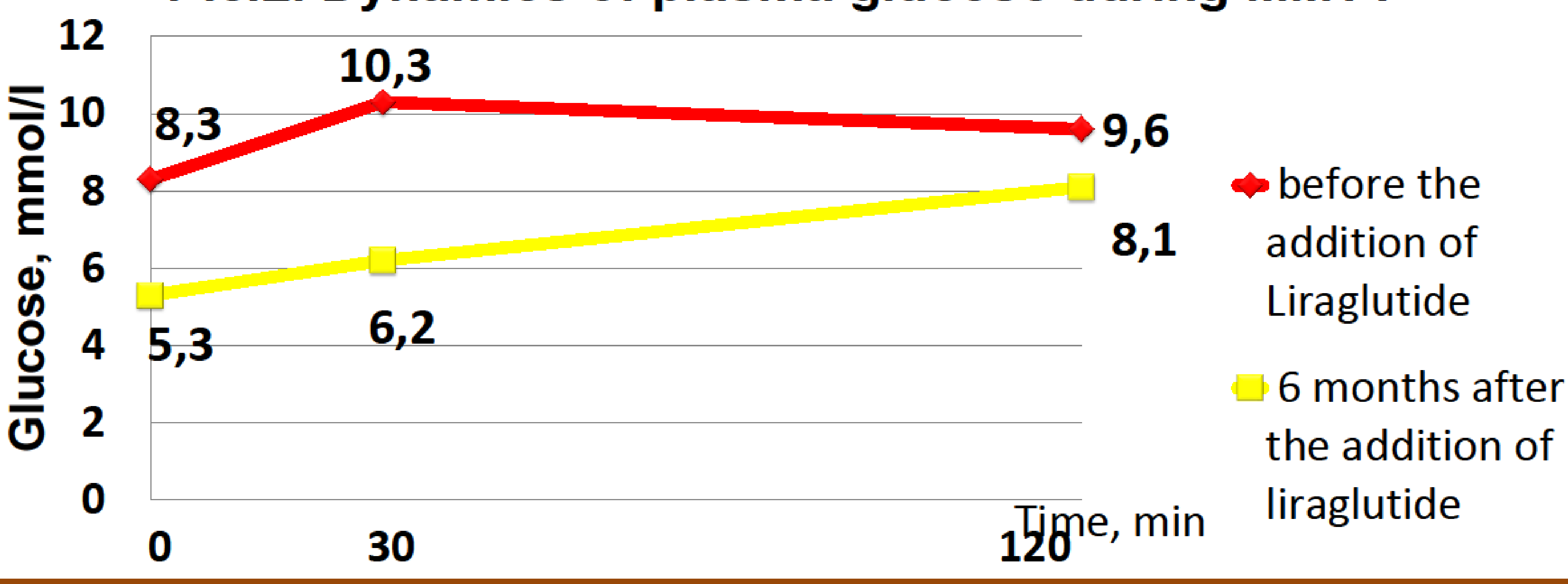

\section{Conclusion}

Addition of liraglutide to insulin in patient with LADA leads to improvement in glycemic control, $\mathrm{HbA} 1 \mathrm{c}$ and reduction in insulin dose and body weight. It reduces glucagon levels and serves to increase C-peptide. 